\title{
Synthesis, Composition and Structure of Complexes of Dialyzed Collagen With CuSO4
}

\section{Adham Rafikov ( $\square$ asrafikov@mail.ru )}

Ташкентский институт текстильной и легкой промышленности https://orcid.org/0000-0002-06386296

\section{Dildora Sadikova}

Tashkent Institute of Textile and Light Industry

Oybek Tursunkulov

Academy of Sciences of the Republic of Uzbekistan Institute of Mathematics and Information Technologies: Academy of Sciences of the Republic of Uzbekistan

Malika Zubaydullaeva

Tashkent Institute of Textile and Light Industry

\section{Research Article}

Keywords: collagen, dialysis, metal complex, composition, crystal structure

Posted Date: December 2nd, 2021

DOI: https://doi.org/10.21203/rs.3.rs-1088902/v1

License: (c) (i) This work is licensed under a Creative Commons Attribution 4.0 International License.

Read Full License 


\title{
Synthesis, composition and structure of complexes of dialyzed collagen with $\mathrm{CuSO}_{4}$
}

Rafikov Adham Salimovich,

Tashkent Institute of Textile and Light Industry, Republic of Uzbekistan

e-mail: asrafikov@mail.ru

ORCID 0000-0002-0638-6296

Sadikova Dildora Bakhramjanovna

Tashkent Institute of Textile and Light Industry

e-mail: dilya198825@mail.ru

Tursunkulov Oybek Muidinovich

Center for Advanced Technologies Ministry of innovation development of Republics Uzbekistan e-mail: oybtm09@gmail.com

Zubaydullaeva Malika Muratovna

Tashkent Institute of Textile and Light Industry

e-mail: magistr.malika@mail.ru

Correspondent author: Rafikov A.S., e-mail: asrafikov@mail.ru Full mailing address: Republic of Uzbekistan, Tashkent, Almazar district, A.Shoshiy street, deadlock 4, house 60.

\begin{abstract}
Coordination complexes of collagen with copper (II) sulfate were synthesized at different ratios of the starting materials. For the synthesis, a collagen solution was used, isolated from the skin of cattle, and then freed from electrolytes by dialysis. With an increase in the salt content, the yield of the reaction product increases. The composition and structure of the complex were determined by FT-IR spectroscopy, SEM, X-ray phase analysis, and differential scanning calorimetry. The complex is formed due to the coordination interaction of $\mathrm{Cu}^{2+}$ with the nitrogen and oxygen atom of collagen and water. An inadequate change in the composition of the complexes with a change in the initial ratio of the components was found. With an excess of collagen, some of it does not bind into a complex and precipitates. With an excess of salt, almost all of the collagen is bound into a complex and a rhombic single crystal is formed. The composition of the complex changes not due to a change in the coordination number $\mathrm{Cu}^{2+}$, but due to an increase in the amount of these ions. An X-ray phase analysis of the starting materials and complexes has been carried out. The correspondence of the parameters of the crystal structure in the X-ray spectra of the complexes was found for a wide ratio of the starting materials. The synthesized complexes have been successfully used for dyeing textile materials.
\end{abstract}

Key words collagen, dialysis, metal complex, composition, crystal structure.

\section{Introduction}

In recent decades, collagen biomaterials have received special attention due to their excellent properties, such as low immunogenicity, biodegradability, biocompatibility, hydrophilicity, ease of processing, etc. [1]. Collagen is one of the most abundant natural proteins and makes up the bulk of animal skins. A review devoted to the production of collagen from animal skins and its physicochemical properties was made in [2]. Collagen differs from all other proteins, especially food proteins, by a high content of proline (11.8\%) and hydroxyproline (9.2\%) [3]. Proline in collagen is present mainly in the sequence glycine $(33.5 \%)$ - proline - $\mathrm{X}$, where $\mathrm{X}$ is often represented by alanine $(10.9 \%)$ or hydroxyproline. Isolation and study of the properties of 
collagen show its high reactivity in the reactions of oxidation [4], hydrolysis [5], curing [6], and graft copolymerization [7]. Collagen is used to obtain a polymeric membrane [8] reinforced with knitted polymeric film material [9]. It is known to form collagen fibers [10], use it in tissue engineering [11] as a framework for nanoparticles [12]. Porous carbon fibers with diameters ranging from 30 to $50 \mu \mathrm{m}$ were obtained by wet spinning collagen materials [13]. Partial hydrolysis of collagen leads to the formation of gelatin [14]. In the textile industry, collagen solution is also used for sizing [15] and fire retardant treatment of cotton yarn before weaving [16] and as part of a composition to impart fire resistance to the material [17].

However, collagen also has some unsatisfactory physical and chemical properties (mechanical strength, thermal stability, enzyme resistance, etc.). Therefore, collagen modification is necessary in the process of obtaining various materials. Metal-containing polymer complexes are ubiquitous in biological systems, and their unique structures provide a variety of biological properties [18, 19]. Combining multiple components or hierarchies from a natural source using a simple method can act as a precursor in the design and application of materials. A biosystem of organometallic compounds based on a collagen fibrous matrix with a chromium (III) complex has been obtained [20]. The resulting complex preserves the internal conformation of collagen and the morphology of its fibers in the skin, showed improved water resistance and air permeability. Revealing the relationship between the structure and the combined properties of the complex contributes to the progress of intelligent protein materials.

Metal ions affect the thermal stability of proteins, increasing or decreasing their resistance to unfolding [21, 22]. The interaction between metal ions and peptides has generated interest due to the important role of metal ions in many biological processes and potential applications in various fields. Conformational changes in peptides depend on the nature of binding to metal ions [23]. Metal ions play a key role in the action of antibiotics and are involved in specific interactions with proteins, nucleic acids, and other biomolecules [24, 25]. The ionimpregnated polymer was synthesized in the system $\mathrm{Cu}^{2+}$ (matrix), 2,2'-bipyridine (ligand) and 4-vinylpyridine (monomer), which forms a coordination complex with the $\mathrm{Cu}^{2+}$ ion, ethylene glycol dimethacrylate (crosslinking agent) and 2,2'-azobisisobutyronitrile (initiator). The polymer has been successfully used for the determination of copper in a multivitamin tablet, various samples of natural waters and industrial effluents [26, 27]. The formation of a complex of a protein with metal ions is used for the sorption of ions from solutions [28]. Nanostructured copper phosphate readily binds to serum albumin [29].

Nucleic bases as protein ligands form complexes with $\mathrm{Zn}^{2+}, \mathrm{Co}^{2+}$ and $\mathrm{Mn}^{2+}$, which consist of endless corrugated one-dimensional chains [30]. Copper participates in several biological processes, forming complexes with protein substances [31, 32, 33, 34]. The coordination complex of copper-bioactive scaffolds was used as a carrier of two anticancer agents [35]. Natural chlorophyll-protein complexes of zinc and silver are of great importance for artificial photosynthetic reactions and antibacterial therapy [36]. Complexes based on $F e^{3+}$ with porphyrins are homogeneous catalysts for the autooxidation of a number of biogenic substances [37]. Collagen membranes, in combination with complexes of gold and nucleic acids, serve as materials for corneal repair, can quickly repair the cornea, and effectively inhibit scar formation [38]. The formation of complexes of proteins with metal ions promotes their crystallization. Moreover, advances in macromolecular crystallization have rapidly multiplied in recent years thanks to the advent of practical, easy-to-use screening kits and laboratory robotics [39].

Thus, complex compounds of metal ions with heteroatom-containing polymers, including proteins, are of great importance in various fields, especially in medicine. Meanwhile, while investigating them as a matrix for drugs, sorbents of various ions, catalysts or inhibitors of chemical processes, not enough attention is paid to the possibility of using them as dyes for textile materials. Complexes of collagen with metal ions, stable over time, are a kind of colored substances. The aim of this work is to synthesize, determine the composition and microstructure of complexes of copper (II) sulfate with collagen for use as a dye for textile material. 


\section{Experimental}

\subsection{Materials}

Collagen solution. Collagen solution was obtained from raw skin of cattle according to the method described in [15].

In order to remove ions and low-molecular substances from the solution, the collagen solution was dialyzed using a dialysis bag made of horse intestine. The time and completeness of dialysis was controlled by the specific conductivity of the solution. In the studies, a collagen solution was used after 24 hours of dialysis, the conductivity of this solution was $46 \cdot 10^{-4} \mathrm{ohm}^{-}$ ${ }^{1} \cdot \mathrm{cm}^{-1}, \mathrm{pH}=6.8$, and the mass fraction of collagen was $6 \%$.

Synthesis of complexes of dialyzed collagen with $\mathrm{CuSO}_{4}$. For the synthesis of the complexes, a $6 \%$ solution of collagen (density $1.02 \mathrm{~g} / \mathrm{ml}$ ) and a $14.4 \%$ solution of $\mathrm{CuSO}_{4}$ (density $1.16 \mathrm{~g} / \mathrm{ml}$ ) were used. Solutions at different mass ratios were placed in a conical flask. During the day, the unreacted part precipitates, which was separated by filtration. Upon evaporation of the filtrate (an aqueous solution of a complex compound), crystals of the $\mathrm{CuSO}_{4}$ complex with collagen are formed. Isolation of the collagen-metal ion complex from the solution is carried out in etonol [40]. In our case, the same final result was obtained both upon evaporation of the filtrate and upon precipitation into ethanol. The complex salts were dried in a Memmert universal drying oven at a temperature of $60^{\circ} \mathrm{C}$ to constant weight.

\subsection{Characterizations}

The $\mathrm{pH}$ of the solutions was determined using an automatic titrator "EasyPlus "TM Titration".

The mass fraction of substances in the solution was determined by the mass of the dry residue.

The density of the solutions was determined by the pycnometric method.

The conductivity of the solutions was determined using an FP30 conductometer.

The FT-IR spectra of the complexes were recorded on a Nicolet iS50 FT-IR spectrophotometer (Thermo Scientific, USA) with an internal reflection attachment and a Continuum microscope.

The study of the microstructure of the complexes was carried out on a scanning electron microscope (SEM EVO MA 10, Zeiss) by method of energy dispersive X-ray spectroscopy (EDX). To conduct localized elemental analysis of a substance, a spectrum of X-rays emitted from the surface of a sample, bombarded by a focused electron beam, is used.

$\mathrm{X}$-ray phase analysis of the initial substances and their complexes was carried out on a diffractometer of the "EMPYREIN" system by the X-ray powder method in the range of " $2 \theta$ angles from 5 to 90 with a step of 0.0130 in the scanning mode. Scan time approximately 40 min, scan type - continuous. The sample length is $10 \mathrm{~mm}$, the anode material is copper, the research temperature is $25^{\circ} \mathrm{C}$. The system automatically registers the Bragg angles of radiation ${ }^{\circ} 2 \theta$ during diffraction by a given radiation, the values of the interplanar distances $\left(\mathrm{d}_{\mathrm{hkl}}\right)$ and the corresponding intensities of the line (I) of the X-ray spectrum.

Thermal properties of coordination complexes of collagen with transition metal ions were investigated using the method of differential scanning calorimetry (DSC). The samples were studied using a Netzsch Simultaneous Analyzer 409 PG (Germany) instrument with a K-type thermocouple (Low RG Silver) and aluminum crucibles. All measurements were carried out in an inert nitrogen atmosphere with a nitrogen flow rate of $50 \mathrm{ml} / \mathrm{min}$. The temperature range of measurements was $0-400^{\circ} \mathrm{C}$, the heating rate was $10 \mathrm{~K} / \mathrm{min}$. The amount of sample per measurement is $20-30 \mathrm{mg}$. The measuring system was calibrated with a standard set of substances $\mathrm{KNO}_{3}, \mathrm{In}, \mathrm{Bi}, \mathrm{Sn}, \mathrm{Zn}, \mathrm{CsCl}$. 


\section{Results and discussion}

\subsection{Collagen solution dialysis}

To carry out chemical reactions, including for the synthesis of a complex of metal ions with protein macromolecules, it is necessary to free the collagen solution from electrolytes. The presence of ions in solution can interfere with the main complexation reaction. To this end, we dialyzed the collagen solution by changing the water in the dialyzer every two hours. Fig. 1 shows the dependence of the specific electrical conductivity of the solution and the mass fraction of the dry residue on the dialysis time.
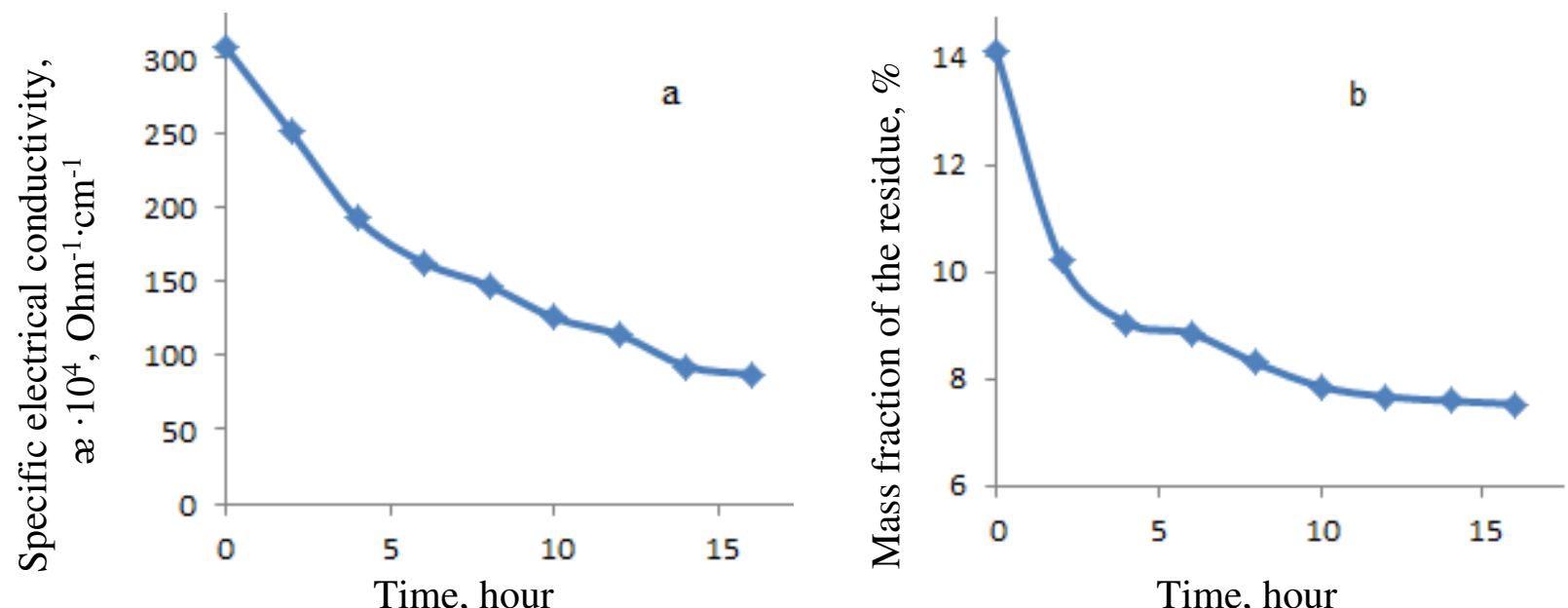

Fig. 1 Dependence of the specific electrical conductivity (a) and the mass fraction of the dry residue (b) of the collagen solution on the dialysis time

As can be seen from the figure, with increasing dialysis time, the electrical conductivity of the solution and the mass fraction of substances in the solution decrease. Moreover, a significant decrease in indicators, especially the mass fraction, is observed during the first hours of dialysis. The main proportion of electrolytes is removed from the solution within 5-6 hours after the second change of water in the dialyzer. Subsequently, a less intense decrease in the electrical conductivity and mass fraction of the solution continues. Apparently, during deep dialysis, low-molecular collagen fractions are removed from the solution, which are also involved in electrical conduction.

\subsection{Synthesis}

The synthesis of complex compounds at different ratios of collagen and copper salt made it possible to preliminarily assess their composition. When determining the number of amino acid units of collagen in moles, the average molecular weight of one unit is calculated as the sum of the products of the molecular weight of one unit by its mass fraction. Table 1 shows the dependence of the yield of the complex compound on the ratio of the components.

Table 1 Initial ratios of components and the yield of a complex compound

\begin{tabular}{|c|c|c|c|c|c|c|c|}
\hline \multicolumn{3}{|c|}{ Collagen } & \multicolumn{3}{c|}{$\mathrm{CuSO}_{4}$} & \multicolumn{2}{c|}{ Complex } \\
\hline solution, g & $\mathrm{G}$ & Mol & solution, g & $\mathrm{G}$ & $\mathrm{mol}$ & $\mathrm{g}$ & $\%$ \\
\hline 2 & 0.12 & 0.0015 & 8 & 1.152 & 0.0072 & 1.5227 & 119.7 \\
\hline 4 & 0.24 & 0.0030 & 6 & 0.864 & 0.0054 & 1.2399 & 112.3 \\
\hline 6 & 0.36 & 0.0045 & 4 & 0.576 & 0.0036 & 0.9106 & 97.3 \\
\hline 8 & 0.48 & 0.006 & 2 & 0.288 & 0.0018 & 0.6669 & 86.6 \\
\hline 9 & 0.54 & 0.0068 & 1 & 0.144 & 0.0009 & 0.5167 & 75.5 \\
\hline
\end{tabular}


As can be seen from the data in the table, with an increase in the mass fraction of $\mathrm{CuSO}_{4}$, the yield of the complex increases. Moreover, with a molar ratio of collagen : $\mathrm{CuSO}_{4}=0.0015$ : 0.0072 and $0.003: 0.0054$, the mass of the complex is greater than the sum of the masses of salt and collagen. This indicates that some of the water is bound into a complex through a coordination bond.

\subsection{FT-IR}

To establish the mechanism of the complexation reaction, FT-IR spectroscopic studies were carried out. FT-IR spectra of collagen (Fig. 2), $\mathrm{CuSO}_{4}$ (Fig. 3) and complexes obtained at different initial ratios of components (Fig. 4) were analyzed.

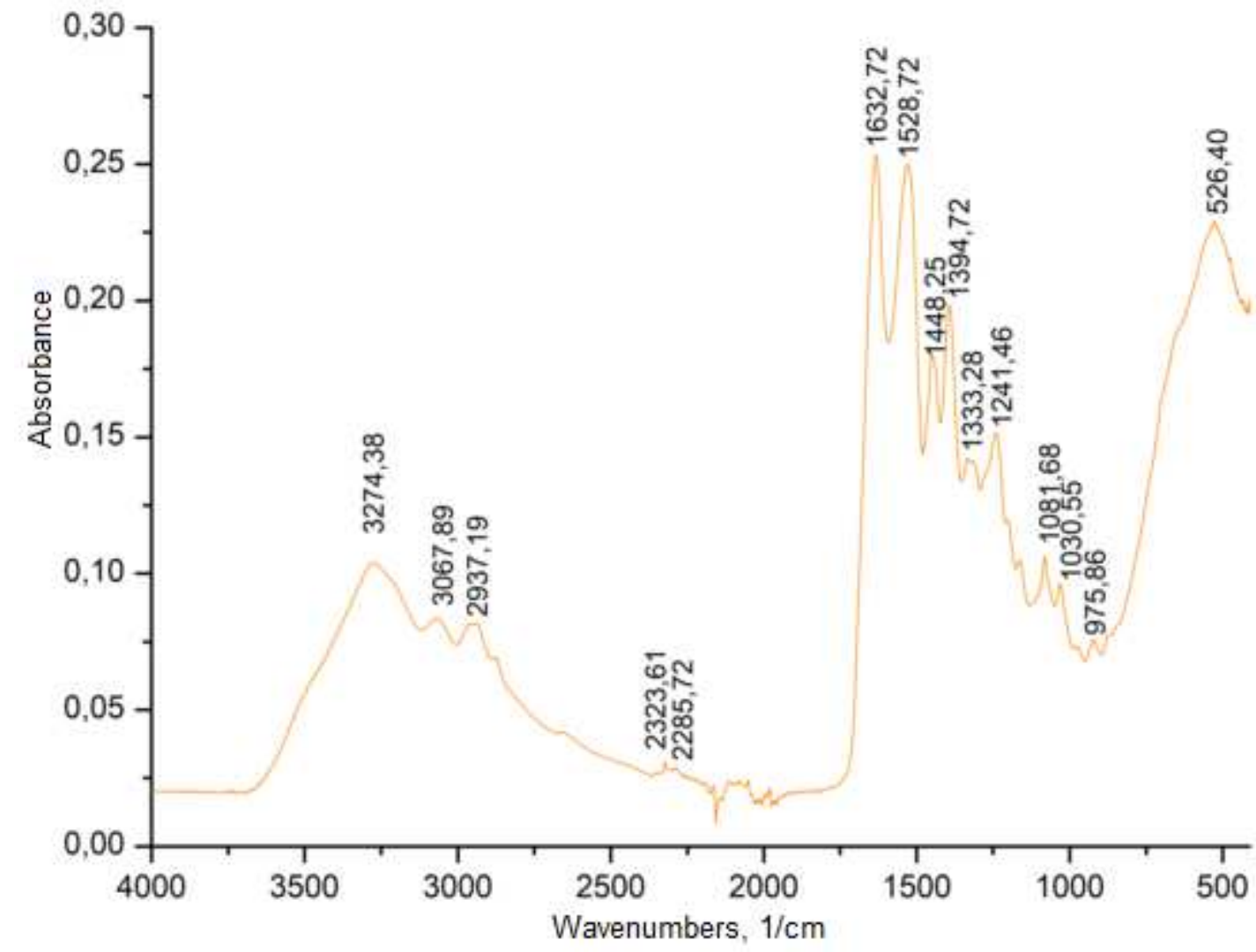

Fig. 2 FT-IR spectrum of collagen

The FT-IR spectrum of collagen revealed absorption bands of stretching vibrations of associated $\mathrm{NH}$ and $\mathrm{OH}$ groups in the region of $3274 \mathrm{~cm}-1$, stretching vibrations $v_{N-H}$ of the peptide group at $3068 \mathrm{~cm}^{-1}$, stretching vibrations $v_{C=O}$ at $1633 \mathrm{~cm}^{-1} 1$ (amide I band), $N H$ bending vibrations at $1528 \mathrm{~cm}^{-1}$ (amide II band) and at $1394 \mathrm{~cm}^{-1}$ (amide III band). The absorption bands at $1233-1202 \mathrm{~cm}^{-1}$ refer to $\delta_{N H}+v_{C N}$. The absorption bands at $1163-921 \mathrm{~cm}^{-1}$ are related to vibrations of $C-O$ bonds. Stretching vibrations of $C-H$ bonds show an absorption band at $2937 \mathrm{~cm}^{-1}$, bending vibrations of these bonds at $1448 \mathrm{~cm}^{-1}$.

In the FT-IR spectra of $\mathrm{CuSO}_{4}$, an absorption band is observed at $1063 \mathrm{~cm}-1$, assigned to the $S_{4}^{2-}$ ion. Weak absorption bands at $1669,865,605-429 \mathrm{~cm}-1$, apparently, refer to the vibrations of the $S=O, O=S=O$ bonds. The absorption band at $3112 \mathrm{~cm}^{-1}$ refers to the stretching vibrations of bonds of associated water molecules. 


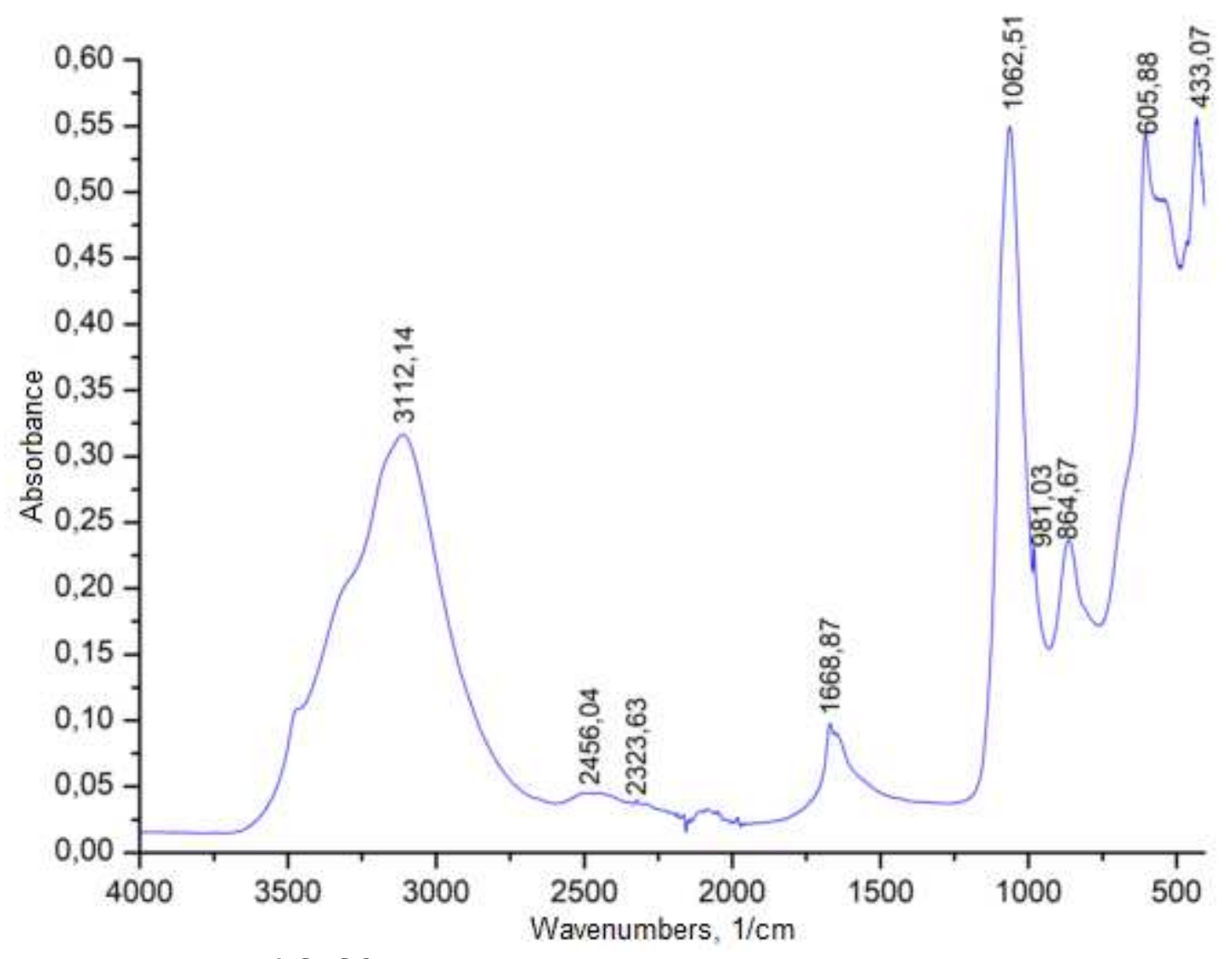

Fig. 3 FT-IR spectrum of $\mathrm{CuSO}_{4}$

In the FT-IR spectra of the complex compounds $\mathrm{CuSO}_{4}$ with collagen, the absorption bands of the initial substances are preserved, but the wave number of the optical density maxima changes, and new signals appear. The complex synthesized at the molar ratio collagen : $\mathrm{CuSO}_{4}=$ $0.0068: 0.0009$ is somewhat different from the complexes synthesized at other ratios. The spectrum of this complex is similar to that of collagen, but a new intense absorption band appears with a maximum optical density at a wavenumber of $1037 \mathrm{~cm}^{-1}$. The new band, apparently, appears as a result of the splitting and shift of the absorption band of vibrations of the sulfate ion of the salt at $1063 \mathrm{~cm}^{-1}$. A shoulder appears on the absorption band of amide I of the complex $\left(1633 \mathrm{~cm}^{-1}\right)$ at $1651 \mathrm{~cm}^{-1}$. A significant decrease in the intensity and a shift of the absorption band of amide III (1394-1417 $\left.\mathrm{cm}^{-1}\right)$ is also observed.

In the spectra of the complexes synthesized at other ratios, there is also a sulfate ion vibration band, the maximum of which is slightly shifted to the high-frequency region $\left(1066 \mathrm{~cm}^{-}\right.$ ${ }^{1}$ ) and the degree of segregation decreases with an increase in the $\mathrm{CuSO}_{4}$ content. 


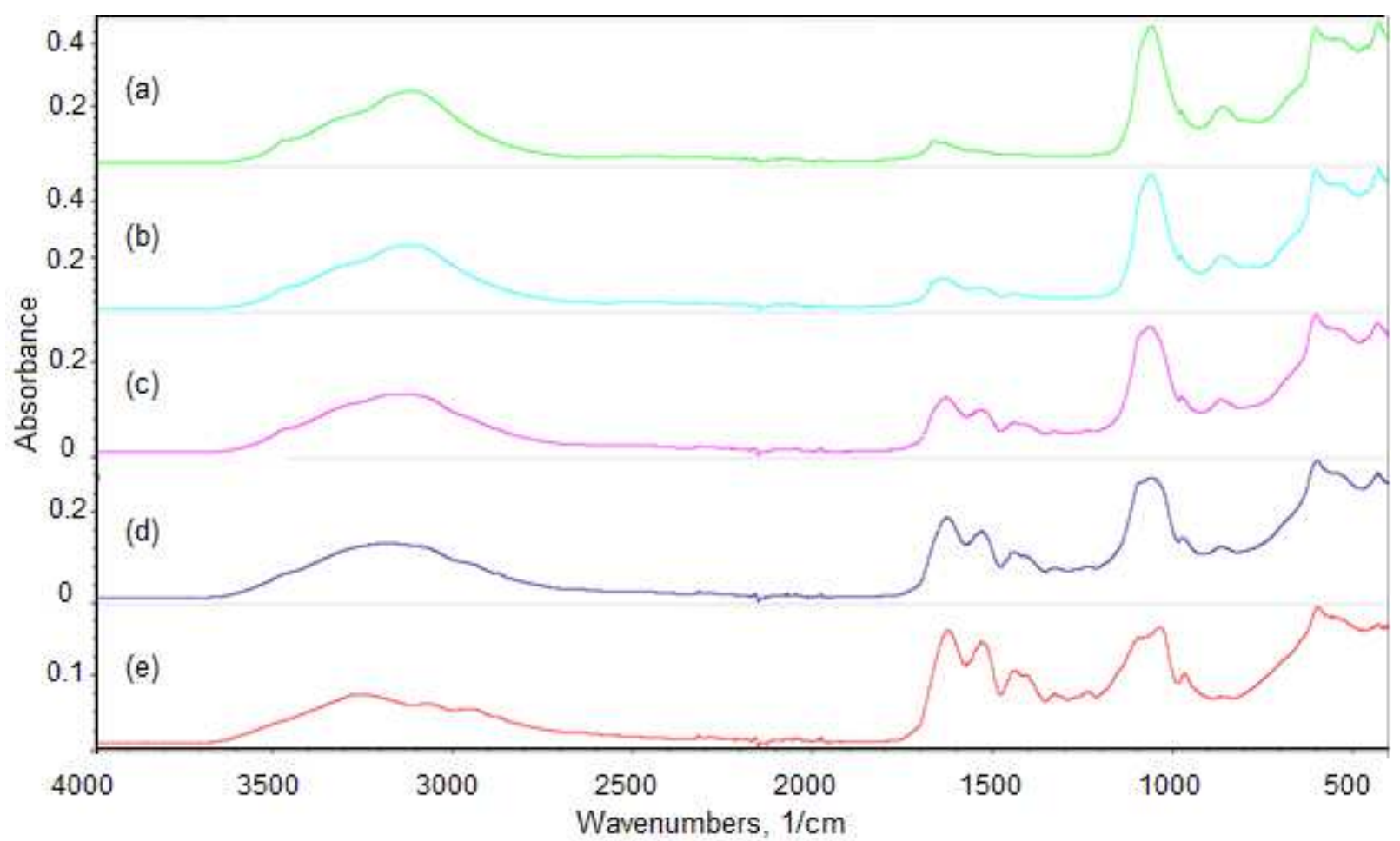

Fig. 4 FT-IR spectra of the complexes synthesized at the initial molar ratio of collagen: $\mathrm{CuSO}_{4}=$ $0.0015: 0.0072$ (a); $0.003: 0.0054$ (b); $0.0045: 0.0036$ (c); $0.006: 0.0018$ (d); $0.0068: 0.0009$ (e)

It is known that the amide and amino groups of the polypeptide can participate in coordination with $\mathrm{Cu}^{2+}$ [41]. The absorption band of stretching vibrations of the associated $\mathrm{NH}$ and $\mathrm{OH}$ groups of collagen in the region of $3274 \mathrm{~cm}^{-1}$, in the complexes shifts to the lowfrequency region. The shift of the absorption band to the low-frequency region assumes the coordination of the compound through the nitrogen and oxygen atoms [42]. Moreover, the degree of shift increases with an increase in the molar fraction of $\mathrm{CuSO}_{4}$ in the initial mixture (table 2). The observed changes in the FT-IR spectra of complex compounds indicate the participation of copper ions, oxygen and nitrogen atoms of collagen, and water oxygen in the coordination interaction.

Table 2 Dependence of the degree of shift of the absorption band of stretching vibrations of $N H$ and $\mathrm{OH}$ groups in the complexes on the initial ratio of components

\begin{tabular}{|c|c|c|c|c|}
\hline \multirow{2}{*}{$\begin{array}{c}\text { Collagen, wave } \\
\text { number, } \mathrm{cm}^{-1}\end{array}$} & $\begin{array}{c}\mathrm{CuSO}_{4}, \text { wave } \\
\text { number, } \mathrm{cm}^{-1}\end{array}$ & \multicolumn{3}{|c|}{ Complex } \\
\cline { 3 - 5 } & & Collagen, mol & $\mathrm{CuSO}_{4}, \mathrm{~mol}$ & $\begin{array}{c}\text { Wave number, } \\
\mathrm{cm}^{-1}\end{array}$ \\
\hline \multirow{3}{*}{3274} & \multirow{3}{*}{3112} & 0.0068 & 0.0009 & 3264 \\
\cline { 3 - 5 } & & 0.0060 & 0.0018 & 3183 \\
\cline { 3 - 5 } & & 0.0045 & 0.0036 & 3165 \\
\cline { 3 - 5 } & & 0.0015 & 0.0054 & 3120 \\
\hline
\end{tabular}

It should be noted that the absorption band of $\mathrm{NH}$ and $\mathrm{OH}$ groups of all complexes is observed as a broad mono signal. This indicates an ordered association of these groups with copper ions. An increase in the degree of shift of these bands from the collagen band to the $\mathrm{CuSO}_{4}$ band indicates an increase in the number of coordinated copper ions with an increase in the amount of salt. This fact also proves the earlier assumption about the participation of water molecules in complexation. 


\subsection{Elemental analysis}

The results of elemental analysis according to SEM data made it possible to supplement the data on the composition of the complex compound (Fig. 5).

a

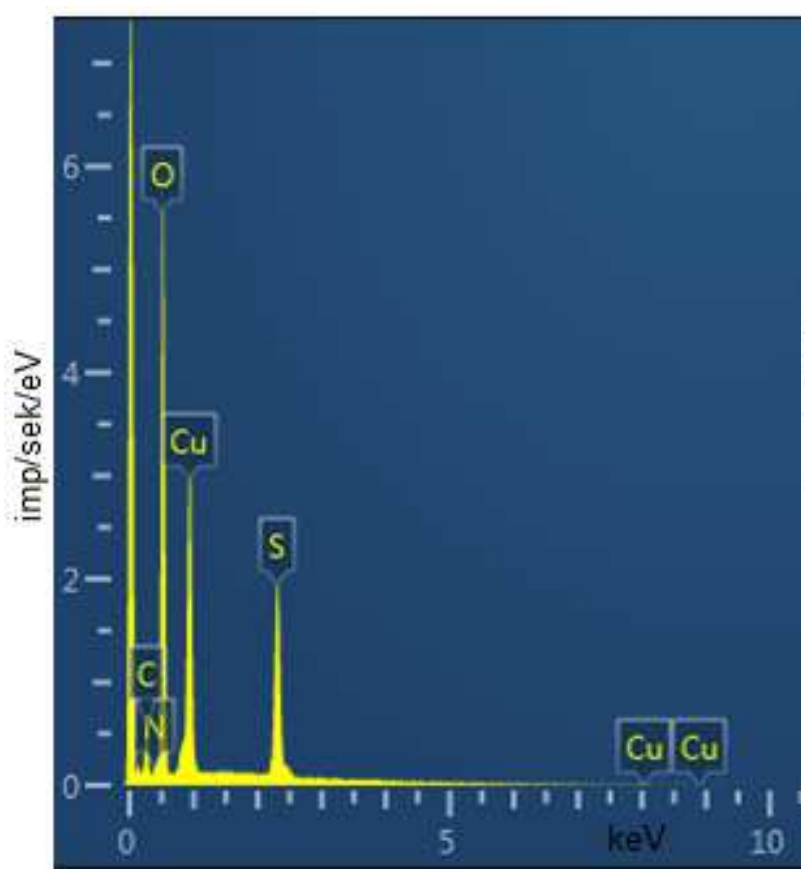

c

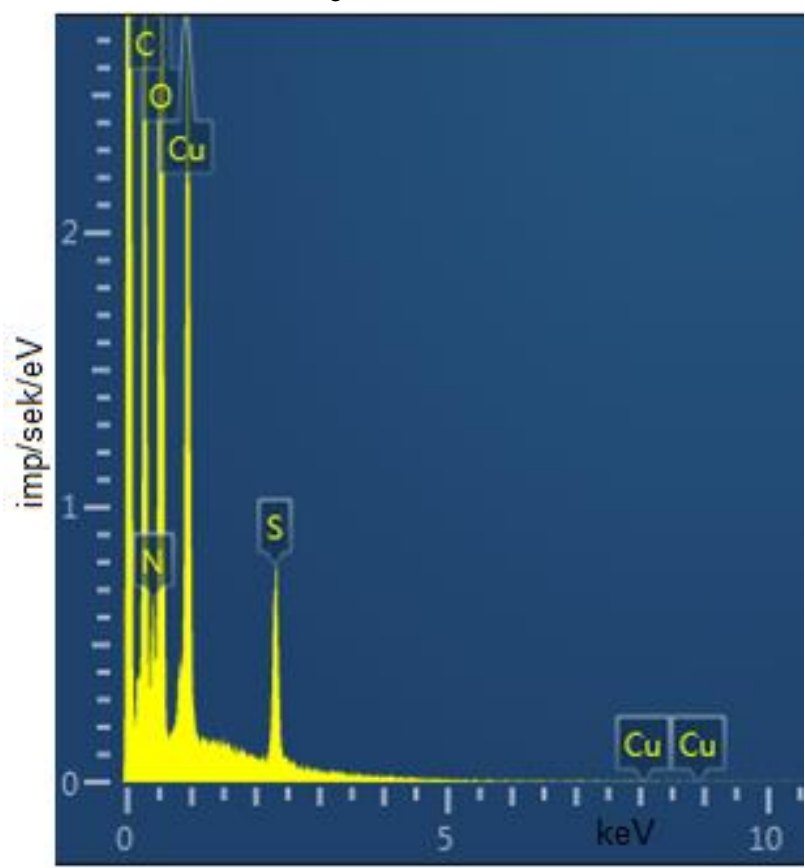

b

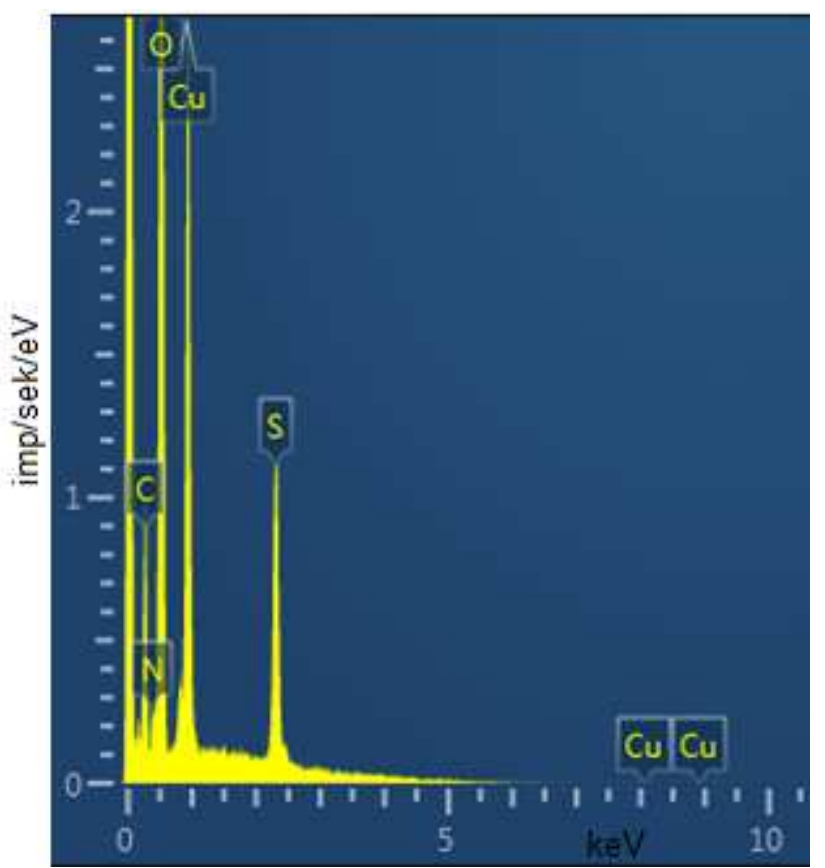

d

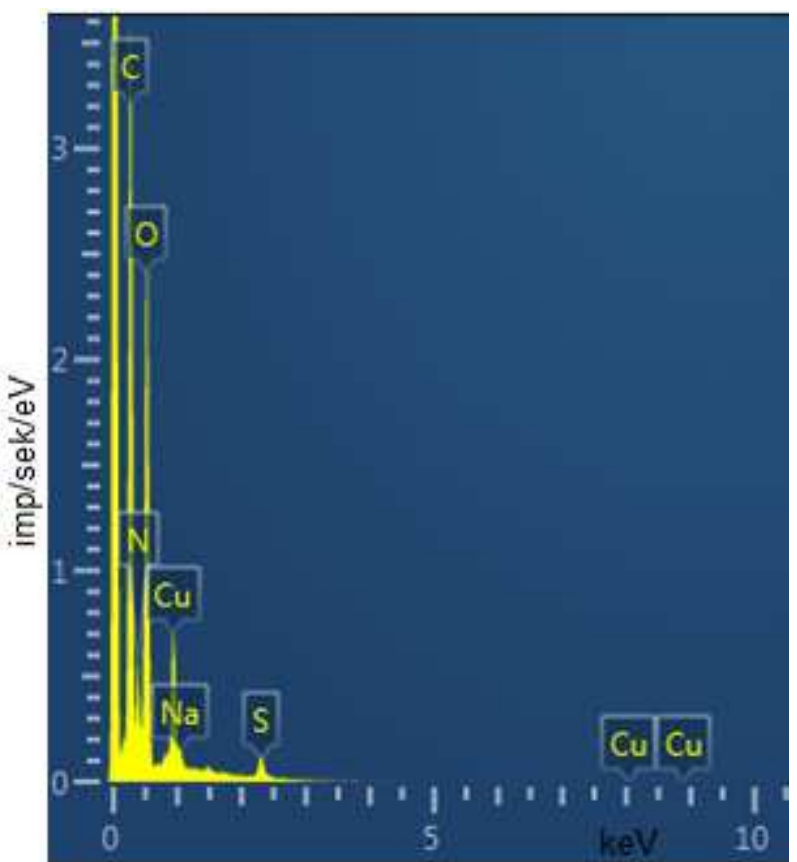

Fig. 5 Elemental composition of complexes synthesized at initial molar ratios of collagen : $\mathrm{CuSO}_{4}=$ a) $0.0015: 0.0072$; b) $0.0030: 0.0054$; c) $0.0045: 0.0036$; d) $0.006: 0.0018$

Table 3 shows the average mass fractions of elements in the composition of complex compounds synthesized with different initial amounts of components. 
Table 3 The elemental composition of the complexes collagen : $\mathrm{CuSO}_{4}$

\begin{tabular}{|l|c|c|c|c|c|}
\hline \multirow{2}{*}{ Element } & \multicolumn{5}{|c|}{ Mass fraction of the element (\%) at the initial ratio collagen : $\mathrm{CuSO}_{4}(\mathrm{~mol}: \mathrm{mol})$} \\
\cline { 2 - 6 } & $0.0068: 0.0009$ & $0.006: 0.0018$ & $0.0045: 0.0036$ & $0.003: 0.0054$ & $0.0015: 0.0072$ \\
\hline $\mathrm{C}$ & 39.72 & 38.78 & 33.75 & 18.91 & 14.58 \\
\hline $\mathrm{N}$ & 14.87 & 14.14 & 11.63 & 6.34 & 4.34 \\
\hline $\mathrm{O}$ & 33.1 & 34.33 & 37.33 & 42.86 & 43.62 \\
\hline $\mathrm{S}$ & 2.6 & 2.85 & 3.4 & 5.33 & 6.45 \\
\hline $\mathrm{Cu}$ & 9.12 & 9.9 & 13.89 & 26.56 & 31.01 \\
\hline $\mathrm{Na}$ & 0.59 & 0.16 & & & \\
\hline
\end{tabular}

Based on the amino acid composition of collagen [3], its macromolecule contains about 2.85 carbon atoms and 1.09 oxygen atoms per 1 nitrogen atom. Based on the results of elemental analysis presented in Table 3, we calculate the ratio of the number of atoms in the complexes (Table 4).

Table 4 The ratio of the number of atoms and the empirical formula of the complexes synthesized at different initial ratios

\begin{tabular}{|l|c|c|}
\hline $\begin{array}{c}\text { Initial ratio collagen }: \mathrm{CuSO}_{4} \\
(\mathrm{~mol}: \mathrm{mol})\end{array}$ & $\begin{array}{c}\text { The ratio of the number of } \\
\text { atoms in the complex, } \\
\mathrm{C}: \mathrm{N}: \mathrm{O}: \mathrm{S}: \mathrm{Cu}\end{array}$ & $\begin{array}{c}\text { Empirical formula of the } \\
\text { complex }\end{array}$ \\
\hline $0.0068: 0.0009$ & $3.14: 1: 1.95: 0.08: 0.13$ & $\left(C_{3.1} \mathrm{H}_{x} \mathrm{NO}_{2} \mathrm{~S}_{0.08} \mathrm{Cu}_{0.13}\right)_{y}$ \\
\hline $0.006: 0.0018$ & $3.23: 1: 2.12: 0.09: 0.15$ & $\left(C_{3.2} \mathrm{H}_{x} \mathrm{NO}_{2.1} S_{0.09} \mathrm{Cu}_{0.15}\right)_{y}$ \\
\hline $0.0045: 0.0036$ & $3.39: 1: 2.81: 0.13: 0.26$ & $\left(C_{3.4} \mathrm{H}_{x} \mathrm{NO}_{2.8} S_{0.13} \mathrm{Cu}_{0.26}\right)_{y}$ \\
\hline $0.003: 0.0054$ & $3.48: 1: 5.92: 0.37: 0.92$ & $\left(C_{3.5} \mathrm{H}_{x} \mathrm{NO}_{5.9} S_{0.37} \mathrm{Cu}_{0.92}\right)_{y}$ \\
\hline $0.0015: 0.0072$ & $3.92: 1: 8.81: 0.65: 1.56$ & $\left(C_{3.9} \mathrm{H}_{x} \mathrm{NO}_{8.8} S_{0.65} \mathrm{Cu}_{1.56}\right)_{y}$ \\
\hline
\end{tabular}

In the complexes collagen : $\mathrm{CuSO}_{4}$, with an increase in the amount of salt, the amount of coordinated copper ions in the complex increases. The fact that the complex contains sulfur indicates that sulfate ions are bound to the complex ion through ionic bonds. At the same time, the number of sulfur and oxygen atoms does not correspond to their number in copper (II) sulfate, sulfur - less, and oxygen - more. Moreover, there is more oxygen, even taking into account the oxygen of the collagen itself. This again suggests that water molecules are involved in coordination with copper ions, especially with an excess content of copper (II) sulfate in the initial mixture.

In the complexes, there are $0.4-0.6$ sulfur atoms and 5.0-6.7 oxygen atoms per copper (II) ion (in copper (II) sulfate, there is one sulfur atom and four oxygen atoms per copper ion). Then only half of the initial amount of sulfate ions turns out to be in the sphere of the anions of the complex. The rest of the anions, apparently, are hydroxo or carboxy ions, which are formed as a result of partial hydrolysis of collagen when it is released from the skin. Taking into account the oxygen of collagen and sulfate ion, 2-3 oxygen atoms remain for each copper ion, which means 2-3 water molecules. If we assume, by analogy with copper sulfate, one water molecule is in the outer sphere of the complex, then 1-2 water molecules are bound to copper as ligands. The coordination number of copper in the complex is four, as evidenced by the geometric shape of the crystals of the complex. The remaining 2-3 ligands of the complex are the nitrogen and oxygen atoms of collagen.

In a wide range of ratios of starting materials, the composition of the synthesized complex does not change adequately, the range of changes in the composition of the complex compound is not wide. Therefore, the yield of the complex compound varies significantly depending on the initial ratio of the components. With a large excess of collagen, some of it does not participate in complexation, precipitates, the yield of the complex is the smallest. With an excess of copper (II) sulfate, the yield of the complex compound was almost quantitative. 
With a change in the ratio of the number of components in the initial mixture, a slight change in the number of carbon atoms is observed. At the same time, the general trend persists: with an increase in the amount of copper (II) sulfate, the mass fraction of carbon in the complex significantly decreases (from 40 to $15 \%$ ), but the number of atoms corresponding to one nitrogen atom slightly increases (from 3.1 to 3.9 atoms). The number and nature of the coordination bonds of the complexing agent, i.e. ion of copper, does not change with a change in the initial ratio of substances. But with an increase in the amount of copper (II) sulfate, the mass fraction of copper ions in the complex increases due to an increase in the number of collagen amino acid residues involved in complexation. In general, the composition and microstructure of the "polymer-metal" complex changes, this leads to a change in the geometric shape of the formed crystals (Fig. 6).
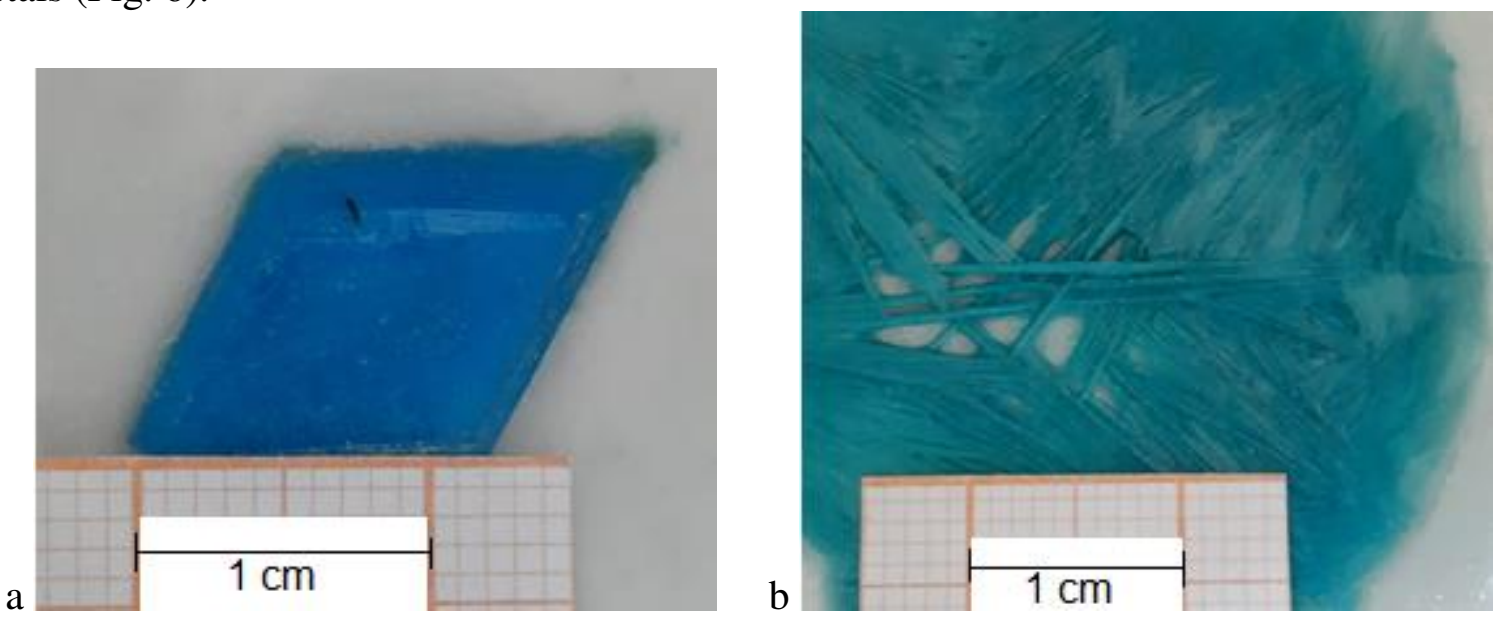

Fig. 6 Photographs of crystals of a complex compound synthesized at the initial ratio collagen : $\mathrm{CuSO}_{4}(\mathrm{~mol}: \mathrm{mol})=0.0015: 0.0072(\mathrm{a}) ; 0.006: 0.0018(\mathrm{~b})$.

As can be seen from Figure 10, the complex synthesized with an excess of copper (II) sulfate has a strictly rhombic shape. The complex, synthesized with an excess of collagen, has a needle-like shape. Moreover, the slow evaporation of the filtered solution of the complex at room temperature makes it possible to obtain a clear rhombic single crystal. Despite the fact that the acceptor of the complex is a substance of polymeric nature, it was possible to form a pure crystal with a coordination number of copper 4 . In this regard, the study of the morphology of complex compounds by the SEM method is of certain interest.

\subsection{SEM}

SEM images of $\mathrm{CuSO}_{4} \cdot 5 \mathrm{H}_{2} \mathrm{O}$, collagen and their complexes synthesized at different initial ratios were analyzed (Fig. 7-9).
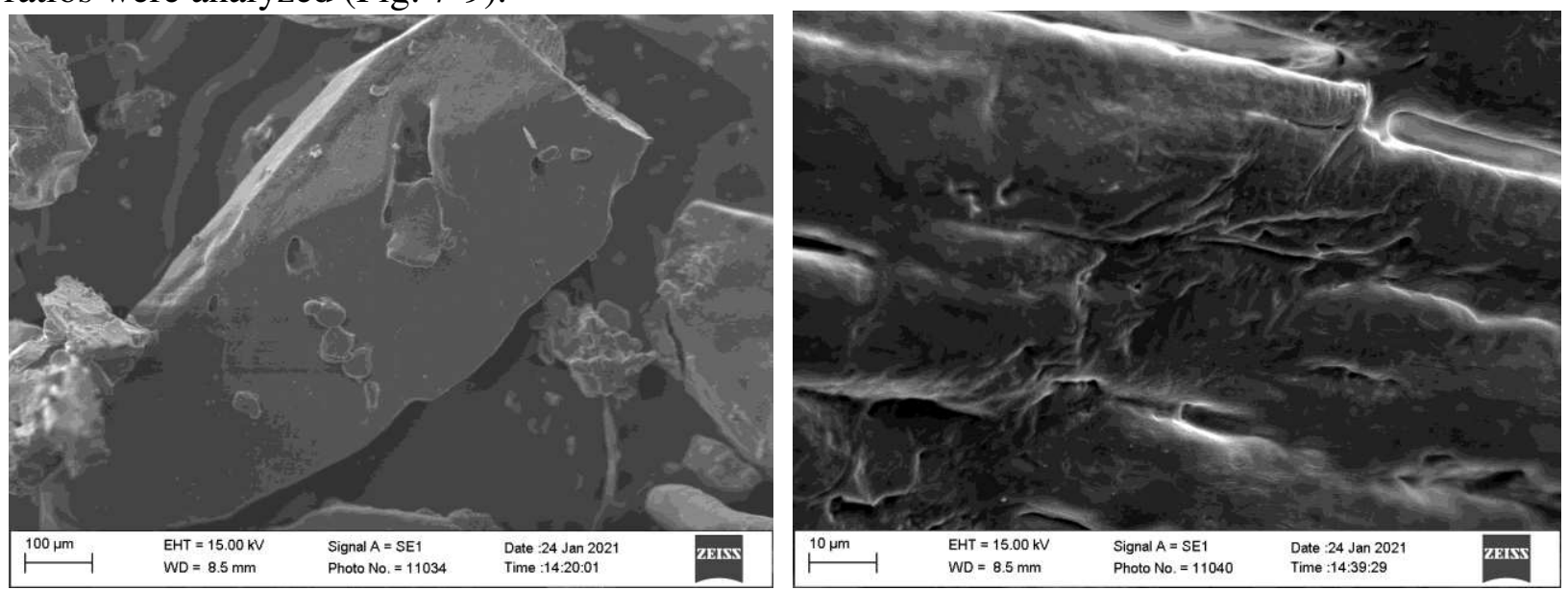

Fig. $7 \mathrm{SEM}$ image of $\mathrm{CuSO}_{4} \cdot 5 \mathrm{H}_{2} \mathrm{O}$ crystals 

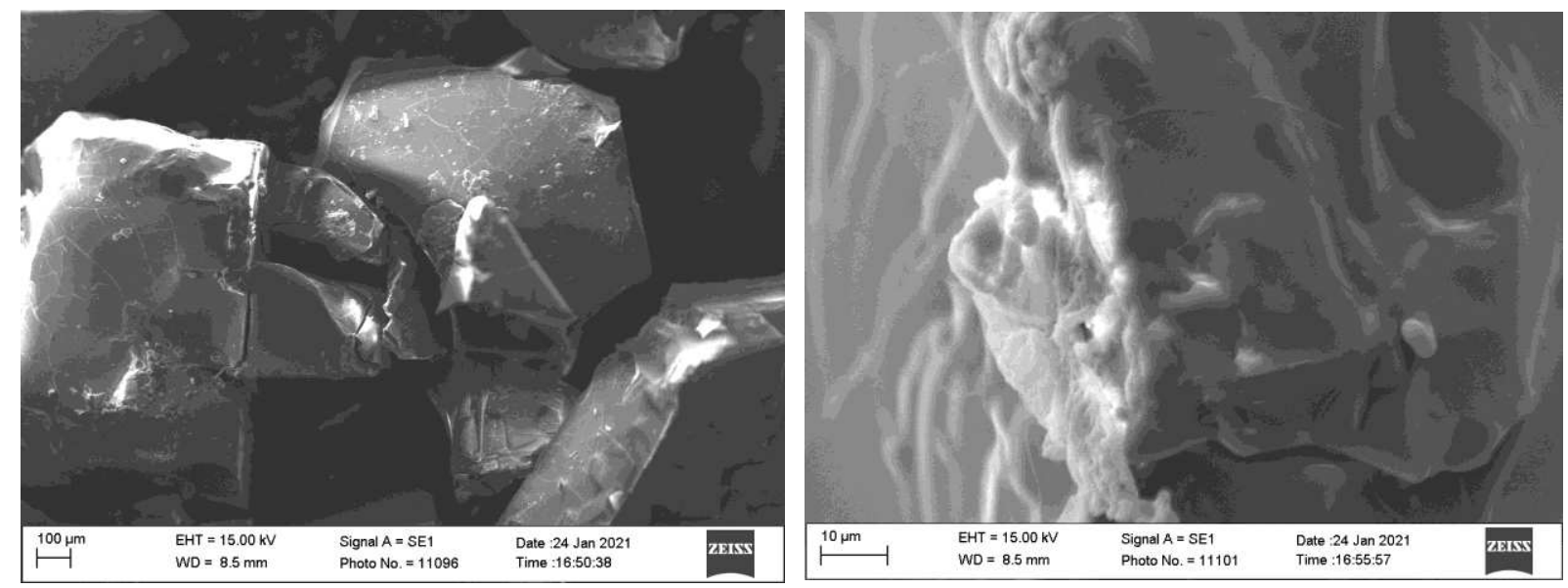

Fig. 8 SEM image of collagen
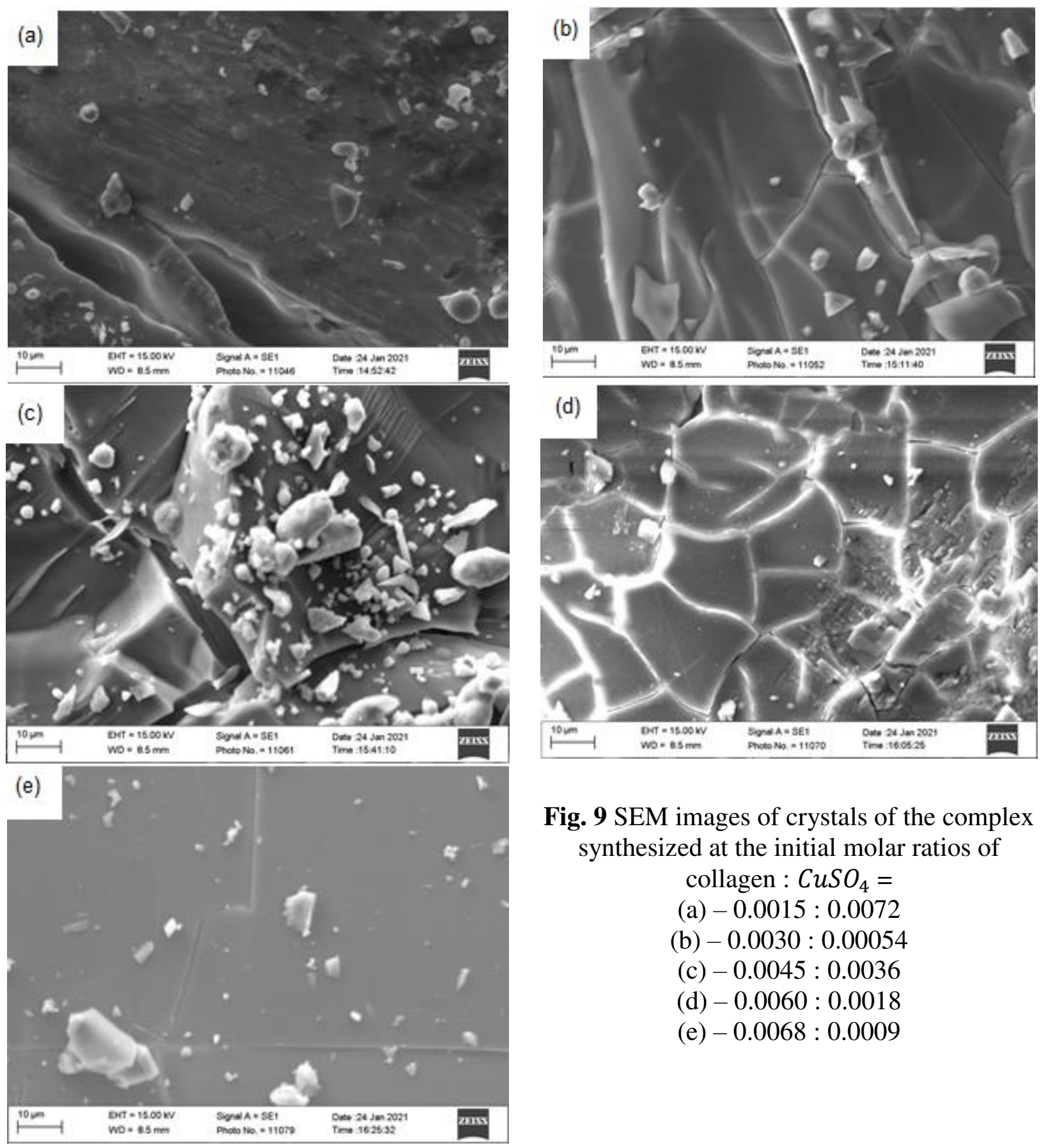

Fig. 9 SEM images of crystals of the complex synthesized at the initial molar ratios of collagen : $\mathrm{CuSO}_{4}=$
(a) $-0.0015: 0.0072$
(b) $-0.0030: 0.00054$
(c) $-0.0045: 0.0036$
(d) $-0.0060: 0.0018$
(e) $-0.0068: 0.0009$ 
As can be seen from Fig. 7, copper sulfate crystals have a dense structure; the level of surface roughness is a few microns. There are intermittent microcracks and depressions on the surface. The surface morphology of individual crystals is formed during the evaporation of water and the formation of copper (II) sulfate pentahydrate.

In terms of surface morphology, collagen resembles an amorphous body with greater roughness than the surface of copper (II) sulfate. On the surface, you can see a very thin grid lines, apparently due to the presence of microcracks (Fig. 8).

Crystals of complex compounds have a more distinct shape with more noticeable microcracks. In them, a noticeable smoothing of the surface occurs with an increase in the collagen content in the initial mixture. The surface morphology of complex compounds once again confirms the closeness of their microstructure. Nevertheless, there are some differences in the composition and structure of the complexes synthesized at different initial ratios of the components. Will this affect the crystal structure of the complexes? Protein is an amorphous substance, and its complexes with metals have a crystalline structure [43]. To clarify this, X-ray phase studies were carried out.

\subsection{X-ray phase analysis}

Were taken X-ray spectra of the starting components and their complex compounds (Fig. 10-12).

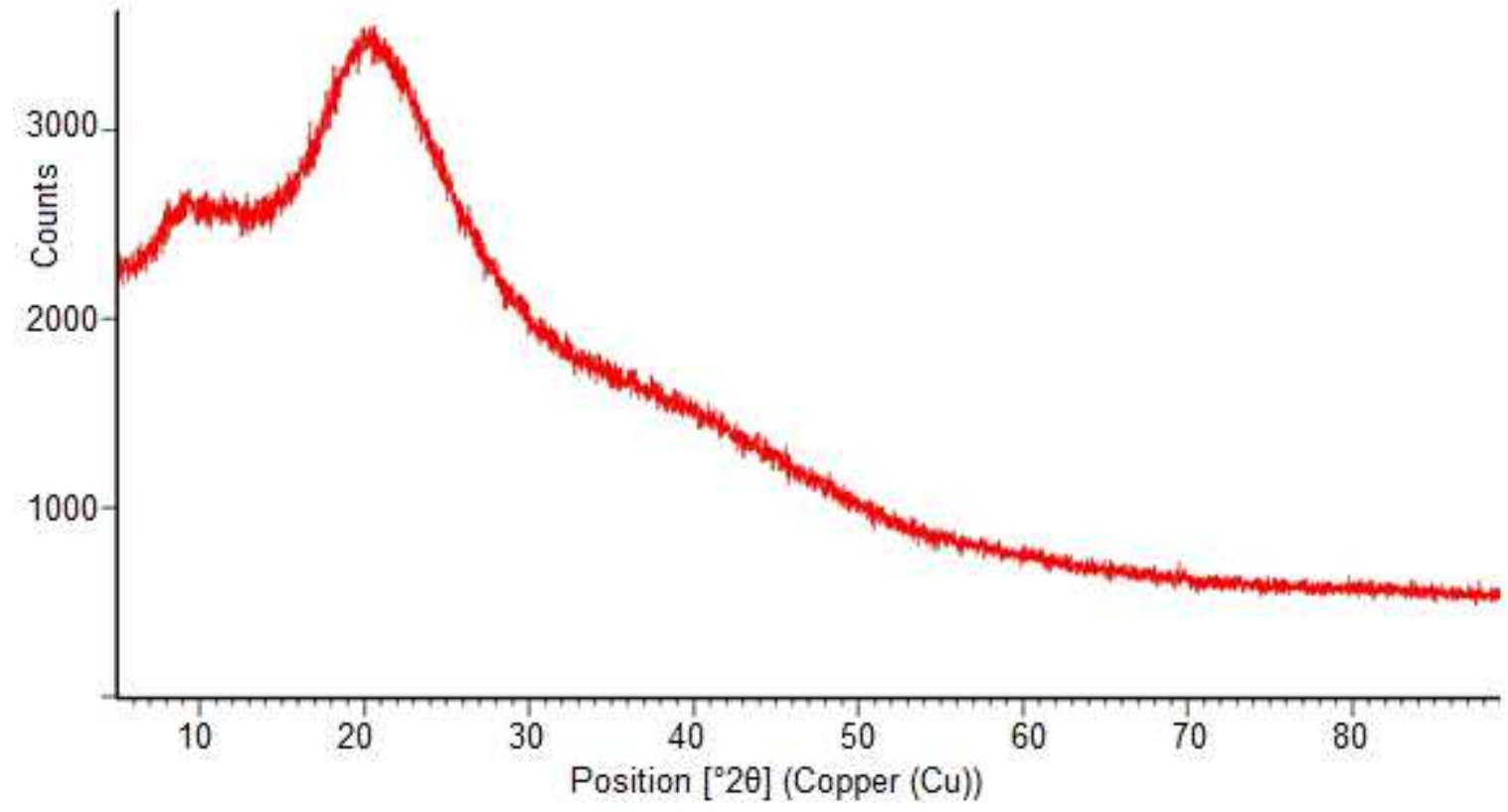

Fig. $10 \mathrm{X}$-ray spectrum of collagen 


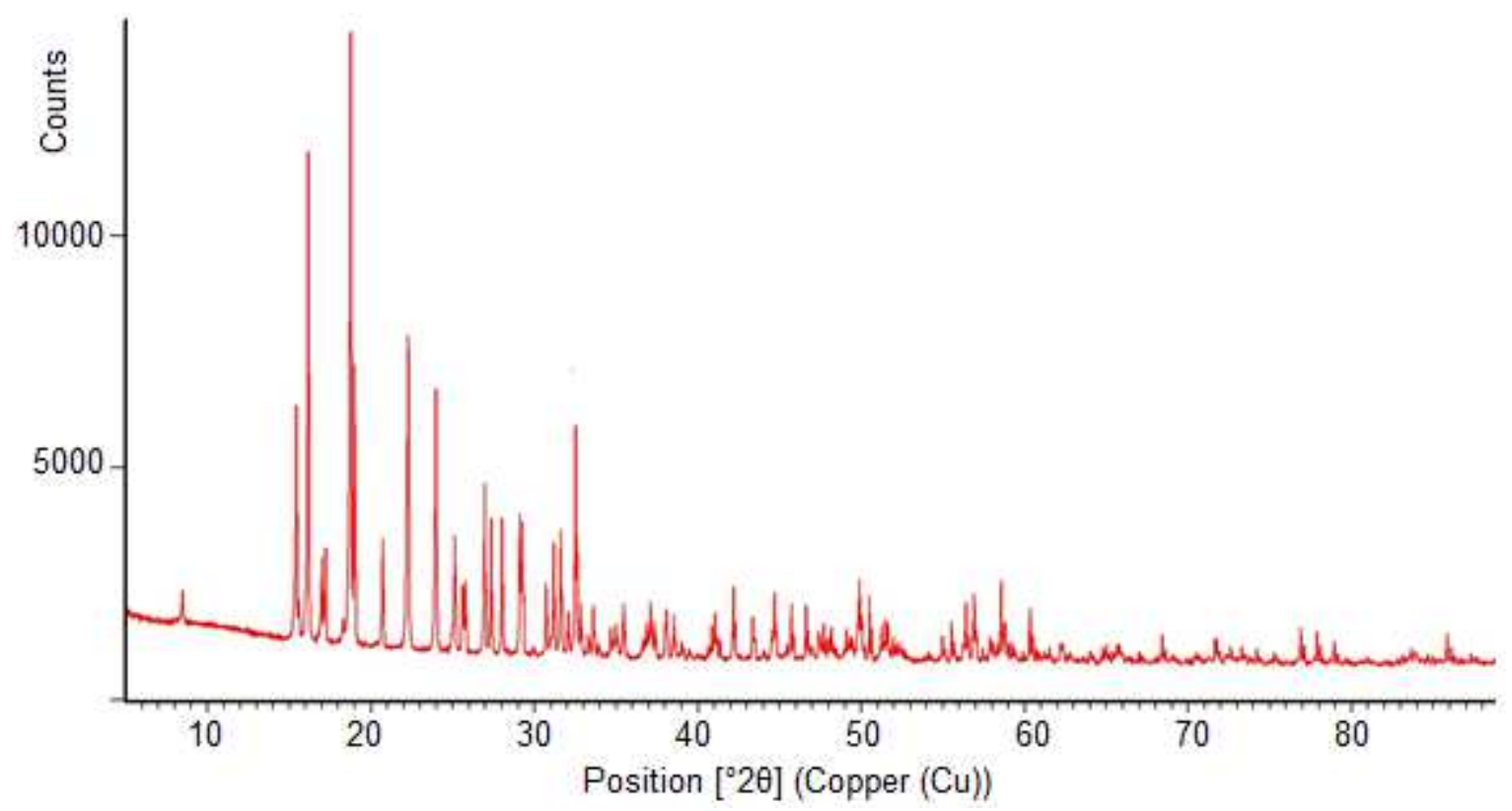

Fig. $11 \mathrm{X}$-ray spectrum of $\mathrm{CuSO}_{4} \cdot 5 \mathrm{H}_{2} \mathrm{O}$

As can be seen from Figures 10 and 11, collagen is almost amorphous, $\mathrm{CuSO}_{4} \cdot 5 \mathrm{H}_{2} \mathrm{O}$ is a purely crystalline substance.

Judging by the X-ray spectra of the complex compounds, the samples retain high crystallinity in a wide range of ratios of the initial substances (Fig. 12). With an increase in the amount of collagen in the complex, the intensity of the crystalline phase reflex slightly decreases. Only with a significant excess of collagen (with the ratio collagen : $\mathrm{CuSO}_{4}=0.0068$ : 0.0009) does the sample turn into an amorphous substance. It is noteworthy that the crystalline phases of all samples exhibit reflections at the same diffraction angles.

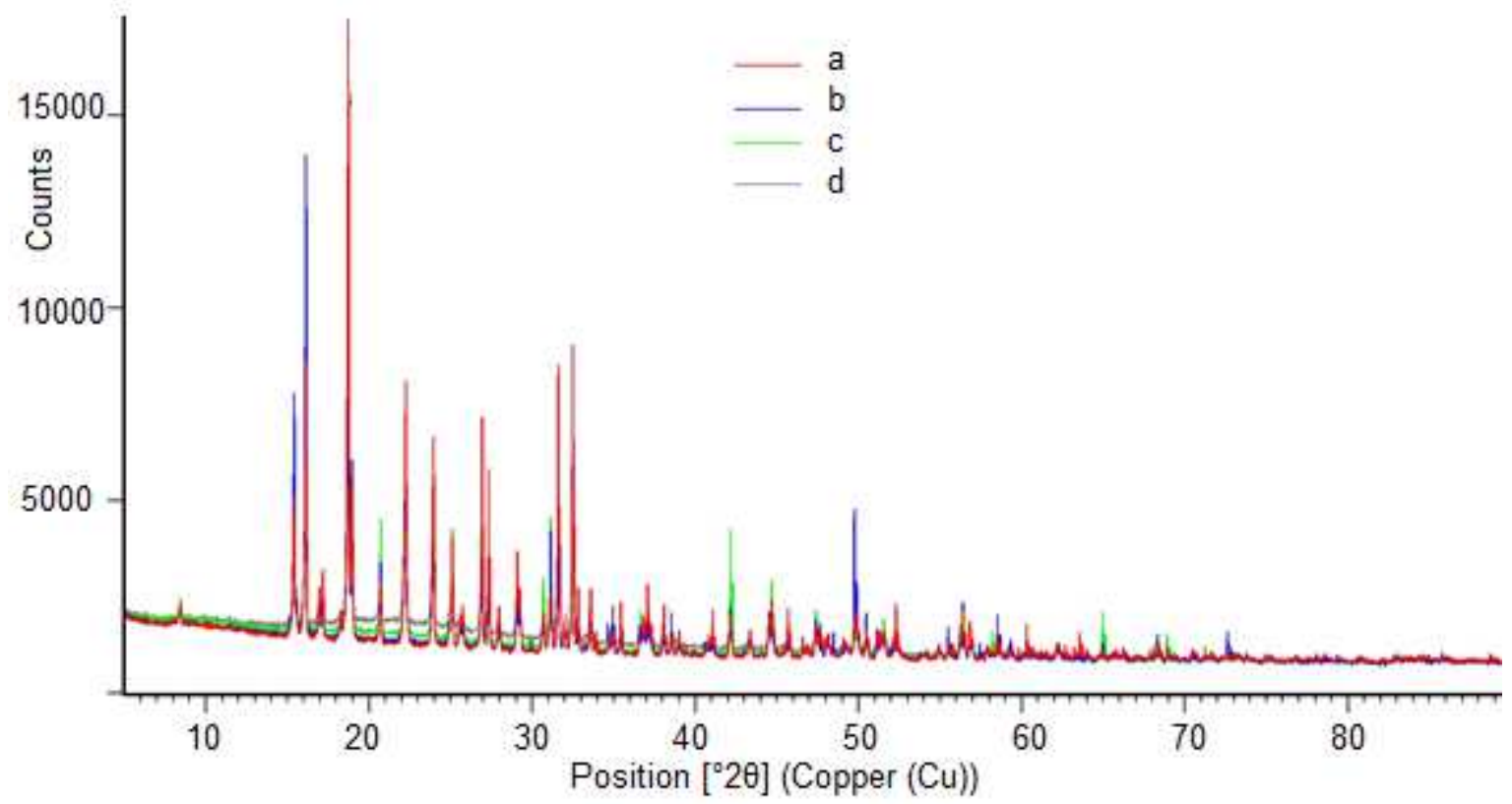

Fig. $12 \mathrm{X}$-ray spectra of complexes synthesized at different initial ratios collagen : $\mathrm{CuSO}_{4}(\mathrm{~mol}$ : $\mathrm{mol})=0.0015: 0.0072(\mathrm{a}) ; 0.003: 0.0054$ (b); $0.0045: 0.0036$ (c); $0.006: 0.0018$ (d) 


\subsection{Thermal properties}

The thermal properties of the complexes were studied by thermogravimetry (TG) and differential scanning calorimetry (DSC) (Fig. 13).

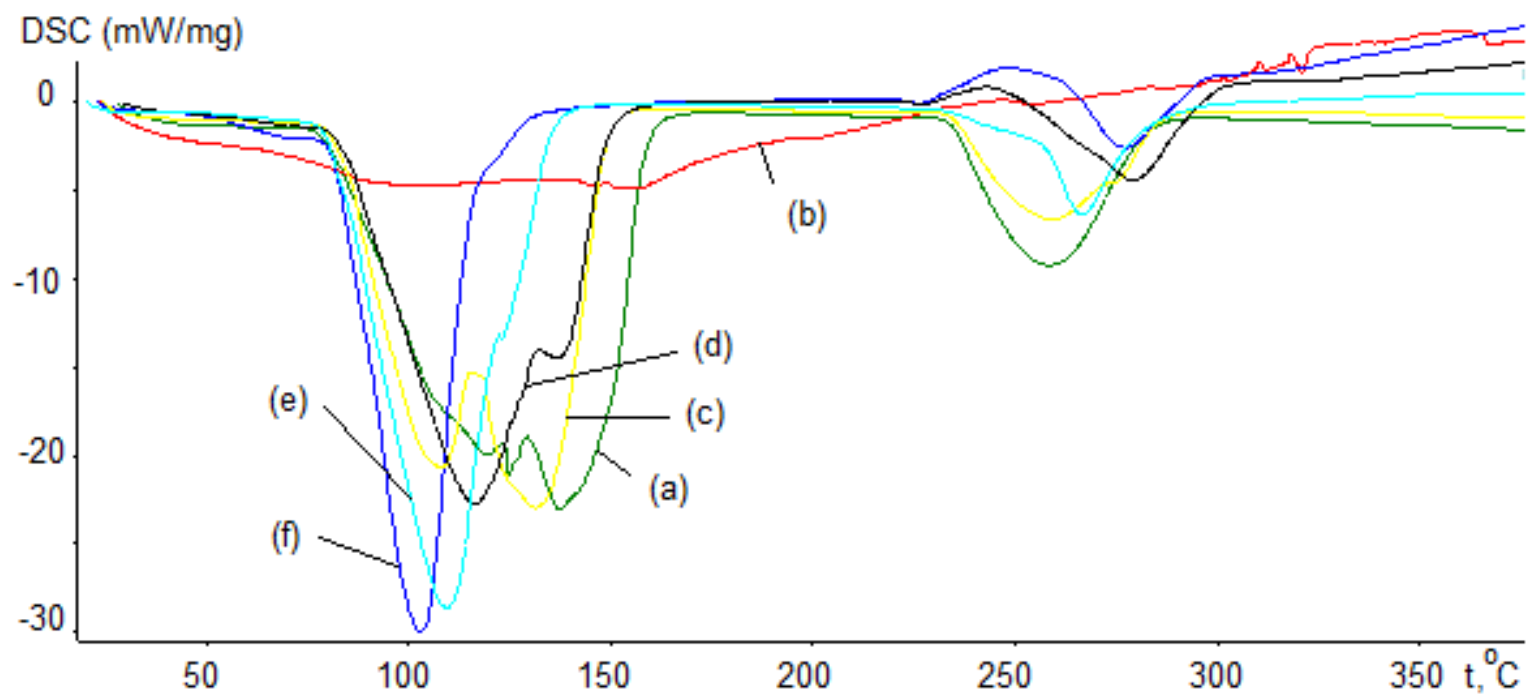

Fig. $13 \mathrm{DSC}$ curves of $\mathrm{CuSO}_{4} \cdot 5 \mathrm{H}_{2} \mathrm{O}$ (a), collagen (b), complexes synthesized at the initial molar ratio collagen : $\mathrm{CuSO}_{4}=0.0015: 0.0072$ (c); 0.0030: 0.0054 (d); 0.0045: 0.0036 (e); 0.0060: 0.0018 (f)

The DSC curve of copper sulfate clearly shows the stages of dehydration - pentahydrate $\left(119.6^{\circ} \mathrm{C}\right)$, trihydrate $\left(125.1^{\circ} \mathrm{C}\right)$, monohydrate $\left(137.5^{\circ} \mathrm{C}\right)$, anhydrous form $\left(258.4^{\circ} \mathrm{C}\right)$. Up to a temperature of $150^{\circ} \mathrm{C}$, four molecules of crystallization water are split off with an absorption of $6839 \mathrm{~J} / \mathrm{g}$ of heat. The cleavage of the fifth crystal water molecule occurs at a higher temperature $\left(260^{\circ} \mathrm{C}\right)$ with the absorption of $1541 \mathrm{~J}$ of heat per $1 \mathrm{~g}$ of crystalline hydrate. In general, the heat of dehydration of copper sulfate is $8.38 \mathrm{~kJ} / \mathrm{g}$.

When collagen is heated to $400^{\circ} \mathrm{C}$, processes with a slight endothermic effect occur. These are the processes of melting and partial decomposition of the polymer with the release of low molecular weight substances.

The DSC curve of the coordination complex synthesized at the initial molar ratio of collagen: $\mathrm{CuSO}_{4}=0.0015$ : 0.0072 clearly shows three endothermic minima $-108.2^{\circ} \mathrm{C}, 131.5^{\circ} \mathrm{C}$, $259.1^{\circ} \mathrm{C}$. The total heat of dehydration of this complex is $7.33 \mathrm{~kJ} / \mathrm{g}$, which is $12.5 \%$ less than the heat of dehydration of copper sulfate. With a decrease in the amount of salt in the complex, the number of endothermic peaks and the total heat of dehydration decrease, and the peaks shift to the low-temperature region.

The DSC curve of the complex synthesized at the initial molar ratio of collagen: $\mathrm{CuSO}_{4}=$ 0.0030: 0.0054 has three peaks $\left(116.7^{\circ} \mathrm{C}, 136.7^{\circ} \mathrm{C}, 279.2^{\circ} \mathrm{C}\right)$ with a total warm dehydration of $6.22 \mathrm{~kJ} / \mathrm{g}$, which is $25.8 \%$ less than the heat of dehydration of copper sulfate. The DSC curve of the complex synthesized at the initial molar ratio of collagen: $\mathrm{CuSO}_{4}=0.0030: 0.0054$ has two peaks $\left(109.6^{\circ} \mathrm{C}, 266.8^{\circ} \mathrm{C}\right)$ with a total heat of dehydration of $5.87 \mathrm{~kJ} / \mathrm{g}$, which is $30.0 \%$ less than the heat of dehydration of copper sulfate. The DSC curve of the coordination complex synthesized at the initial molar ratio of collagen: $\mathrm{CuSO}_{4}=0.0060$ : 0.0018 has two peaks $\left(103.1^{\circ} \mathrm{C}, 277.3^{\circ} \mathrm{C}\right)$ with a total warm dehydration of $4.20 \mathrm{~kJ} / \mathrm{g}$, which is $49.9 \%$ less than the heat of dehydration of copper sulfate.

The shift of endothermic peaks to the low-temperature region with an increase in the amount of collagen and a decrease in the heat of dehydration indicate a decrease in coordinated water molecules. 
On the basis of the studies carried out, variants of the structure of the complexes are proposed.

With excess of collagen:
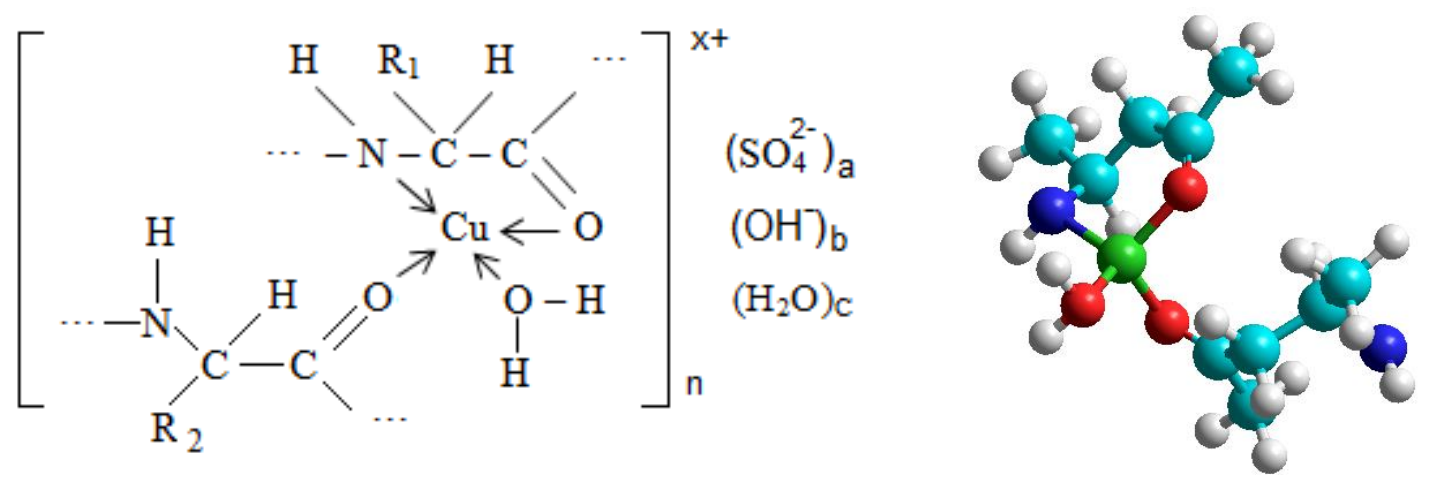

With an approximate equality of collagen and $\mathrm{CuSO}_{4}$

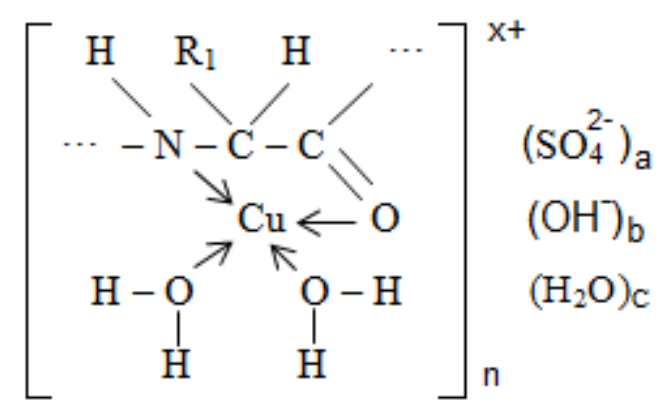

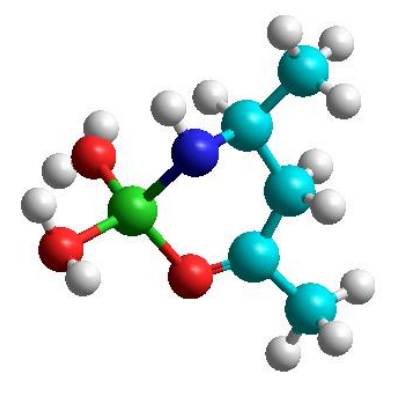

With an excess of $\mathrm{CuSO}_{4}$

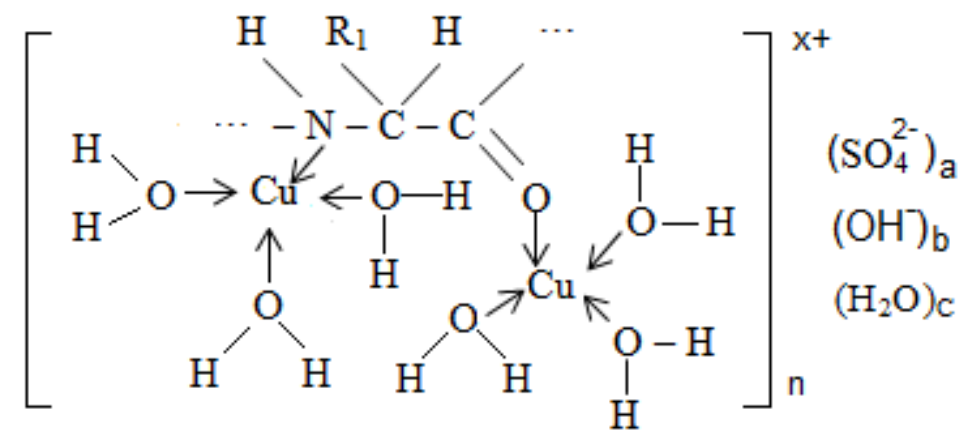

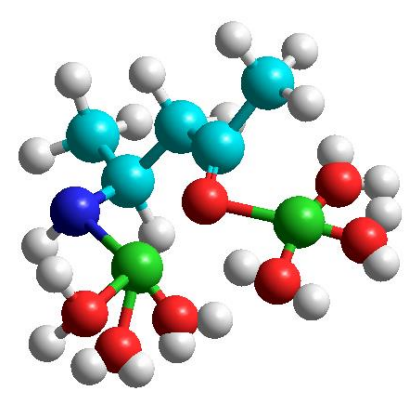

Other variants of the structural formula of the complex are possible. Depending on the initial ratio of the components, the number of copper ions and water molecules in the inner and outer spheres of the complex changes.

\subsection{Practical use}

The synthesized collagen metal complexes were tested as dyes for a cotton textile material, as well as a material made from a mixture of cotton and polyester fibers. When dyeing mixed material, special attention should be paid to the process of preparing the material. Decoction in a soap-soda solution and further mercerization in a sodium hydroxide solution promote the formation of a microporous tissue structure, adsorption and diffusion of the dye. In the process of heat setting, the dye is fixed on the fibers of the material. Technological modes of preparation and dyeing of the material are shown in table 5. 
Table 6 Technology of material dyeing with collagen : $\mathrm{CuSO}_{4}$ complex

\begin{tabular}{|l|l|}
\hline Decoction & In soap-soda solution, temperature $90-95^{\circ} \mathrm{C}, 2$ hours \\
\hline Flushing & In water, at room temperature \\
\hline Mercerization & $18 \% \mathrm{NaOH}$ solution, at room temperature, 30 minutes \\
\hline Flushing & In water, at room temperature \\
\hline Wringing & Up to $90-100 \%$ moisture \\
\hline Dyeing & In the solution collagen : $\mathrm{CuSO}_{4}$, at $40^{\circ} \mathrm{C}, 10$ minutes \\
\hline Wringing & Up to $80-90 \%$ moisture \\
\hline Drying & At room temperature \\
\hline Thermofixation & At $125-130^{\circ} \mathrm{C}, 3-5$ minutes \\
\hline
\end{tabular}

The uniformity of staining was assessed by the images of the appearance of the dyed samples, the color stability - by the change in color intensity and the loss of sample weight after washing in a soap-soda solution. As a result of dyeing a cotton-polyester blend fabric, the best color uniformity was achieved at $\mathrm{pH}=9$, and the color strength at $\mathrm{pH}=7$.

\section{Findings}

For successful chemical reactions involving collagen isolated from the skin of an animal with a dilute alkali solution, the solution should be freed from electrolytes. The main proportion of electrolytes is removed from the solution within 5-6 hours after the second change of water in the dialyzer. When mixing solutions of copper (II) sulfate and collagen, a complex compound collagen : $\mathrm{CuSO}_{4}$ is formed. In a wide range of ratios of starting materials, the composition of the synthesized complex does not change adequately, the range of changes in the composition of the complex compound is not wide. The yield of the complex compound decreases with an increase in the amount of collagen in the initial mixture. With a large excess of collagen, some of it does not participate in complexation and precipitates. As shown by electronic images, complex compounds have a smoother surface with microcracks than the original substances. Collagen and the complex synthesized with a significant excess of collagen are amorphous substances. The complexes synthesized in a wide range of ratios of the starting substances (molar excess of $\mathrm{CuSO}_{4}$ up to five times, excess of collagen up to three times) turned out to be polycrystalline substances. It was possible to obtain a single crystal of the complex synthesized with an excess of $\mathrm{CuSO}_{4}$, which has a rhombic shape. The crystals of the complex synthesized with a slight excess of collagen are needle-shaped. The DSC curves of the complexes showed a decrease in the number of endothermic peaks and the overall thermal effect of dehydration with an increase in the amount of collagen; this indicates a decrease in the amount of water of crystallization. A formula for a complex compound has been proposed, according to which the oxygen and nitrogen atoms of collagen, as well as the oxygen atoms of water, are electron acceptors. Synthesized complex collagen : $\mathrm{CuSO}_{4}$ can be used as a stable dye for cotton and cottonpolyester fabrics.

\section{Reference}

1. X. Liu, Ch. Zheng, X. Luo, X. Wang, H. Jiang, Mater Sci and Engineering. C, 99 (2019), p. 1509-1522, DOI:10.1016/ j.msec.2019.02.070

2. K. Tang, F. Wang, P. Iia, J. Liu, K. Wang, J Amer Leather Chem Assoc, 2 (2007), p.52-61

3. D. Prockop, A. Fertala, J Biol Chem, 273 (1998), p. 15598-15604. doi: 10.1074/jbc.273.25.15598.

4. D. Rabinovich, Regulation of the chemical activity of collagen: redefining the Hofmeister effect. World Leater 3 (2008), p. 26-29. https://pubs.rsc.org > 
5. Yu. Tikhonova, L. Krivonosova, S. Lomkin, E. Filatova, R. Khabibullin R, Bashkir Chem J, 1 (2009), p. 13-15, https://www.mdpi.com/1420-3049/24/22/4031/pdf.

6. J. Bo, Z. Yong, Y. Zheng, W. Zhihong, H. Guanglin, L. Libin, Z. Xingdong,. J Appl Polym Sci, 5 (2005), p. 2094-2100

7. M. Sahiner, D. Alpaslan, B. Bitlisli, Polym Bull, 71 (2014), p. 3017-3033, https://doi.org/10.1007/s00289-014-1235-X

8. R-E. Scutariu, G. Batrinescu, G. Nechifor, Polym Engineering and Sci (2020), https://doi.org/10.1002/pen.25486

9. S. Karimov, A. Rafikov, A. Ibragimov, M. Askarov, Inter Polym Sci and Technology, 42 (2015), p. 47-49, https://doi.org/10.1177/0307174X1504200408

10. J. Moncy V, T. Vinoy, D. Derrick R, N. Elijah, Polymer, 15 (2009), p. 3778-378515, https://www.cheric.org > doi10.1016/j.polymer.2009.05.035

11. J. Song, P. Zhang, L. Cheng, Y. Liao, B. Xu, R. Bao, W. Wang, W. Liu, J of materials chem, B3 (2015), p. 4231-4241, https://doi.org/10.1039/C5TB00205B

12. M. Vedhanayagam, M. Nidhin, N. Duraipandy, N. Naresh, G. Jaganathan, M. Ranganathan, M. Kiran, S. Narayan, B. Nair, K. Sreeram, Inter J of Biological Macromol, 99 (2017), p. 655664, https://pubmed.ncbi.nlm.nih.gov>

13. N. Salim, X. Jin, S. Mateti, H. Lin, V. Glattauer, B. Fox, J. Ramshaw, Materials Today Advances, 1 (2019), p. 31-38, https://doi.org/10.1016/j.mtadv.2019.100005

14. M. Khan, M. Sadiq, Polym Bull, 1 (2020), p. 31-38, https://doi.org/10.1007/s00289-02003283-4

15. A. Rafikov, M. Khakimova, D. Fayzullayeva, A. Reyimov, Cellulose, 27 (2020), p. 1036910384, http://link.springer.com/article/10.1007/s10570-020-03450-w

16. A. Rafikov, O. Yuldosheva, S. Karimov, M. Khakimova, D. Abdusamatova, M. Doschanov, J of Industrial Textiles, (2020), https://doi.org/10.1177/1528083720957410

17. N. Nabiev, Md. Raju, A. Rafikov, H. Quan, Asian J of Chem, 29 (2017), p. 2470-2475, https://doi.org> ajchem.2017.20776

18. Q. Xu, M. Xu, C. Lin, Y. Tian, Z. Xia, Advanced Sci. 6

(2019),

https://www.ncbi.nlm.nih.gov> doi: 10.1002/advs.201902043

19. R. Herrick, C. Ziegler, T. Leeper, J of Organometallic Chem (2014), https://doi.org/10.1016/j.jorganchem.2013.07.004

20. Y. Han, Y. Jiang, J. Hu, X. Chen, Materials \& Design (2020), DOI: 10.1016/j.matdes.2019.108206

21. A. Sorenson, P. Schaeffer, Analytica Chimica Acta, 11018 (2020), p. 120-128, http://актуальность.pф > ES-31_originalmaket_N

22. B. Wieczorek, H.P. Dijkstra, M.R. Egmond et al, J of Organometallic Chem (2009), https://doi.org/10.1016/j.jorganchem.2008.12.010

23. Z. Liu, S. Chen, F. Qiao, X. Zhang, Inter J of Mass Spectrometry, 438 (2019), p. 87-96, https://doi.org/10.1016/j.ijms.2018.12.016

24. S. Turmanova, I. Dimitrov, E. Ivanova et al, Polym Bull, 72 (2015), p. 1301-1317, https://link.springer.com > article

25. M. Jeżowska-Bojczuk, K. Stokowa-Sołtys, European J of Medicinal Chem, 1431 (2018), p. 997-1009, DOI: 10.1016/j.ejmech.2017.11.086

26. J. Shah, M. Jan, Anjum, J of Analytical Chem (2018), DOI: 10.1134/S1061934818120055 .

27. D. Gafurova, B. Khakimzhanov, M. Mukhamediev, U. Musaev, Russian J of Applied Chem, 75 (2002), p. 71-74, https://doi.org/10.1023/A:1015568907375

28. N. Nematidil, M. Sadeghi M, Polym Bull, 76 (2019), p. 5103-5127, https://doi.org/10.1007/s00289-018-2646-X

29. B. Önal, Ö. Acet, V. Dzmitruk V et al, Polym Bull (2021), https://doi.org/10.1007/s00289021-03557-5

30. J. García-Terán, G. Beobide, O. Castillo, J. Cepeda, A. Luque, S. Pérez-Yáñez, P. Román, Polyhedron, 171 (2019), p. 53-64, https://doi.org/10.1016/j.poly.2019.07.001 
31. G. Tabbì, A. Magrì, E. Rizzarelli, J of Inorganic Biochem, 199 (2019), DOI:10.1016/ j.jinorgbio.2019.110759

32. S. Sukkur, M. Sankarganesh, P. Adwin, J. Dhaveethu, Inorganic Chem Communications, 124 (2021), https://doi.org/10.1016/j.inoche.2020.108396

33. S. Nishino, Y. Ishikava, Y. Nishida, Inorganic Chem Communications, 2 (1999), p. 438-441, https://doi.org/10.1016/S1387-7003(99)00120-3

34. T. Ueno, T. Koshiyama, S. Abe, N. Yokoi, M. Ohashi, H. Nakajima, Y. Watanabe, J of $\begin{array}{lllll}\text { Organometallic } & \text { Chem, } & 692 & \text { (2007), } & \text { p. }\end{array}$ https://doi.org/10.1016/j.jorganchem.2006.08.043

35. S. Sharma, D. Mittal, A. Verma, I. Roy, ACS Appl Bio Materials (2019), https://doi.org/10.1021/acsabm.9b00116

36. Z. Chai, Y. Wang, S. Chen, H. Chen, H. Yang, X. Guo, F. Wu, J of Polymer Research (2019), https://doi.org/10.1007/s10965-019-1735-3

37. A. Olkhov, A. Lobanov, O. Staroverova, P. Tyubaeva, A. Zykova, P. Pantyukhov, A. Popov, A. Iordanskii, A Physical-chemical and antibacterial properties IOP Conf Series: Mater Sci and Engineering, 175 (2016), Inter Conf on Competitive Materials and Technol Processes, IC-CMTP 2016; Miskolc-Lillafured; Hungary; October

38. X. Zhao, W. Song, Y. Chen, S. Liu, L. Ren, Biomat Sci, 7 (2019), p. 51-62, DOI: 10.1039 / c8bm01054d.

39. A. McPherson, Methods in Molecular Biology, 1607 (2017), p. 17-50, doi: 10.1007/978-14939-7000-1_2

40. H. Liu, S. Wang, Y. Xi et al, Polym Bull, 64 (2010), p. 835-843, https://doi.org/10.1007/s00289-009-0228-7

41. B. Rivas, A. Maureira, C. Guzman et al, Polym Bull, 67 (2011), p. 763-774, http://goo.gl/Krj9eA

42. G. Lupas su, E. Pahonțu, S. Shova et al, Appl Organomet Chem, 35 (2021), https://doi.org/10.1002/aoc.6149

43. X. Li, B. Wang, Y. He et al, Polym Bull, 78 (2021), p. 713-728, https://doi.org/10.1007/s00289-020-03121-7 